\title{
"POVOS QUASE DA MESMA LÍNGUA": NÃO-/TRADUÇÃO, MODERNIZAÇÃO, E AS RELAÇÕES BRASIL-ARGENTINA, 1865-1900
}

\author{
PEOPLES OF THE SAME LANGUAGE: NON/TRANSLATION, \\ MODERNIZATION, AND BRAZILIAN-ARGENTINE RELATIONS, 1865- \\ 1900
}

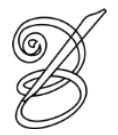 \\ Ori PREUSS ${ }^{2,3}$ \\ Universidade de Tel Aviv, Israel \\ Tradutores \\ Patrícia Rodrigues COSTA ${ }^{4}$ \\ Universidade de Brasília, Brasil \\ Rodrigo D'AVILA ${ }^{5}$ \\ Universidade Federal de Santa Catarina, Brasil \\ Lia Araujo Miranda de LIMA ${ }^{6}$ \\ Universidade de Brasília, Brasil \\ Giovana BLEYER ${ }^{7}$ \\ Universidade Federal de Goiás, Brasil
}

RECEBIDO EM: 28 de fevereiro de 2019

ACEITO EM: 26 de março de 2019

PUBLICADO EM: abril 2019

PREUSS. "Povos quase da mesma língua”: não-/tradução, modernização, e as relações Brasil-Argentina, 1865- 


\section{“POVOS QUASE DA MESMA LÍNGUA": NÃO-/TRADUÇÃO, MODERNIZAÇÃO, E AS RELAÇÕES BRASIL-ARGENTINA, 1865-1900}

"Me siento feliz por no poder hablaros en español, porque doy así prueba de que considero tan unidas, tan hermanas nuestras nacionalidades, tan vinculado el pueblo brasileño al generoso pueblo argentino, como hermanos son nuestros idiomas, que se comprenden, que se confunden, que tienen el mismo origen y la misma suavidad." O congressista brasileiro Serzedelo Correia proferiu estas palavras no começo de seu discurso ao Congresso argentino em 29 de outubro de 1900, como parte das festividades que envolviam a visita do presidente brasileiro Campos Sales a Buenos Aires, retribuindo a visita de Julio Roca, seu homólogo argentino, ao Rio de Janeiro no ano anterior. "Sí! Si el idioma es uno de los elementos que más electrizan a un pueblo y una nacionalidad en la unidad de sus ideales, de sus ideas, en la conformidad de sus costumbres, en la convergencia de sus sentimientos, en la identidad de sus dolores, de sus alegrías," continuou a desenvolver sua ideologia da linguagem, então "los idiomas que nosotros hablamos están para decirnos que nuestros destinos se confunden como

136 se confunden las aguas del Plata y del Amazonas con el Océano, las cuales, en una larga extensión, afirman su individualidad, pero habiendo momentos en que no se sabe dónde terminan los ríos $\boldsymbol{y}$ dónde comienza el mar."8

Os dois maiores rios da América do Sul e a noção de fusão de cursos d'água e dos destinos regionais ressurgiram cinco anos depois no contexto de outro encontro sul-americano, quando um delegado argentino ao $3^{\circ}$ Congresso Científico Latino-Americano, realizado no Rio de Janeiro com o apoio do Ministério das Relações Exteriores brasileiro, apresentou, em espanhol, um memorando sobre a "Unión de los afluentes navegables del Amazonas y del Plata." ${ }^{9}$ Os dois eventos - as visitas presidenciais de 1899/1900 e o congresso científico de 1905 -, juntamente com os conceitos e as propostas dos dois oradores, oferecem exemplos e metáforas para a crescente circulação de pessoas e de informações através das fronteiras nacionais na América do Sul e a proliferação interrelacionada de projetos macrorregionais culturais, políticos e materiais durante o final do século XIX e início do século XX.

Historiadores têm ignorado em grande medida essa crescente conexão e seu papel na formação de espaços geopolíticos e geoculturais como um objeto de investigação próprio. Fortemente informada pela teoria da dependência ou pós-colonial, e altamente centrada no Estado-nação, a história da América Latina do século XIX girou em torno de relações de poder extremamente desiguais - sejam relações de dominação, confrontação ou negociação -, tanto 
entre os centros do Atlântico Norte e a periferia latino-americana quanto dentro cada país dessa periferia. Seja escrevendo a partir de uma abordagem top-down ou bottom-up, implícita ou explicitamente, estudiosos modernos têm direcionado sua atenção para duas esferas de interação principais: a primeira, entre as classes privilegiadas da América Latina e da Europa ou dos Estados Unidos, e a segunda, entre essas classes privilegiadas e seus respectivos "povos".

Esse artigo defende a importância de uma terceira esfera, amplamente ignorada, de intercâmbio cultural, mais horizontal em termos de poder, através das fronteiras nacionais, entre os grupos étnicos e sociais da América Latina, ou o que também pode ser chamado de histoire croisée, uma história cruzada, da região, que deve ser distinguida da história comparada. "Dentro de uma perspectiva da histoire croisée, o transnacional [...] é compreendido como um nível que existe em interação com os outros, produzindo suas próprias lógicas com efeitos do feedback sobre outras lógicas estruturadoras do espaço." ${ }^{10}$ Este nível apresenta uma relevância particular no caso da América Latina, dada à realidade pós-colonial da região de fortes rupturas etnoculturais dentro das fronteiras "nacionais" e fortes semelhanças etnoculturais para além delas. O estado latino-americano precedeu a nação, emergindo no começo do século XIX do que pode ser rotulado como culture area (área cultural), o produto de mais de três séculos de domínio de colonização Ibérica. Além disso, elites pós-coloniais, com exceção do Brasil, tendiam a dar pouca ênfase à diferenciação cultural de seus respectivos países em relação aos demais quando progrediram para produzir as identidades nacionais. Na América Hispânica, a predominância de uma língua "prejudicou as distinções em termos linguísticos que serviam frequentemente para diferenciar nações na Europa" e facilitou intercâmbios culturais, produção coletiva de saberes locais e identificação, para além da escala do Estado. ${ }^{11}$

Isso era verdade especialmente em relação às classes privilegiadas dos crioulos descendentes de europeus, cujos membros eram fortemente apegados à cultura francesa ou inglesa e profundamente alienados da parcela não branca da população. E isso ainda era verdade, talvez até mais, durante o final do século XIX e início do século XX, um período da história da América Latina famoso pela integração da região à economia mundial, pela modernização da infraestrutura, urbanização, cosmopolitismo cultural, e consolidação do estado central sob a liderança das elites liberais conservadoras. Embora essas tendências tenham sido amplamente documentadas, os historiadores raramente refletiram sobre sua contribuição para aproximar as classes letradas e predominantemente brancas da América Latina, tanto no 
sentido físico quanto mental. De fato, foram, sobretudo, os críticos literários com inclinações históricas e sociológicas, tal como Ángel Rama e Susana Zanneti, que chamaram atenção para como a modernização, e, especialmente, como as melhorias no transporte e na comunicação, juntamente com um esforço sistemático por parte de escritores, contribuíram para a expansão e para o estreitamento de conexões literárias entre diferentes cantos da América hispânica da década de 1870 à de 1900. Zanneti e Rama designaram essa tendência "sem precedentes" como religación (amarração), ou religación interna, na definição mais precisa de Rama, delineada para diferenciar os laços transnacionais na região dos laços externos com os países do Atlântico Norte. $^{12}$

Seguindo o trabalho ainda pioneiro destes investigadores, este artigo amplia o estudo sobre religación, levando-o para além do domínio da América hispânica e do campo da literatura, de modo a incluir a América portuguesa e as políticas internacionais. Isso se dá ao se focar na transferência e na tradução de textos não literários entre Brasil e Argentina, empregando princípios teóricos derivados dos Estudos Descritivos da Tradução, da Sociologia da Literatura, da História do Livro e da abordagem histoire croisée. ${ }^{13}$

\section{Rumo a uma história transnacional da tradução dentro da América Latina}

A história da tradução entre Brasil e a América hispânica no decorrer do longo século XIX é uma área especialmente negligenciada de toda uma vasta e inexplorada história da tradução na América Latina como um todo. Em parte, isso se dá em razão de uma lacuna de longa data entre historiadores e especialistas dos Estudos da Tradução. Tal como Peter Burke notou, apesar da chamada "virada histórica" nos Estudos da Tradução desde a década de 1980, “os especialistas desse campo de estudo têm menos a dizer sobre os contrastes entre culturas do que sobre tradutores em particular, menos sobre tendências de longo prazo do que sobre processos de curto prazo, e menos sobre a história da prática do que sobre a história da teoria". Historiadores, por sua vez, têm prestado pouca atenção à tradução como um assunto em si e aos Estudos da Tradução como uma disciplina auxiliar. ${ }^{14}$

Além dessa falha de comunicação geral entre as disciplinas, a tradução na América Latina também sofreu pela posição periférica na geopolítica global do conhecimento. Assim, apesar da aparente importância da tradução na história colonial e pós-colonial da região algumas pessoas argumentariam, em razão de sua própria posição periférica -, pesquisas sobre este tema foram deixadas para trás em relação àquelas sobre tradução em países centrais. 
Entretanto, as últimas três décadas viram uma tendência crescente em relação à escrita sobre esse tópico, principalmente por críticos literários e por especialistas dos Estudos da Tradução, inspirados por princípios teóricos derivados da abordagem descritiva, frequentemente associada aos nomes de Even-Zohar e Toury. ${ }^{15}$

De acordo com essa abordagem, estudos mais recentes têm tratado a tradução como uma atividade situada em um tempo e um lugar específicos, em vez de compará-la abstratamente ao texto fonte, e têm começado a questionar a identidade dos tradutores, as ações e motivações por trás das escolhas de textos específicos a serem traduzidos e para qual público-alvo e qual objetivo declarado e/ou oculto a tradução foi realizada. Birgit Scharlau divide o corpus de estudos resultante em três grupos. O primeiro grupo de estudos lidou com o contato entre as culturas ameríndias e europeias. O segundo grupo concentrou-se na tradução de textos literários externos à América Latina, principalmente europeus e norte-americanos, e no papel deles na formação das literaturas nacionais do continente. Finalmente, o terceiro grupo abordou a tradução na América Latina sob uma perspectiva pós-colonial, enfatizando a função da tradução nas relações de poder coloniais ou neocoloniais. ${ }^{16}$

É fácil ver como as trocas interlinguais entre a América portuguesa e a hispânica foram deixadas intocadas por esses tipos de estudo, que parecem compartilhar uma fixação por cismas culturais profundos e/ou por relações de poder extremamente desiguais, uma fixação que muitas vezes vai de mãos dadas com a reificação da diferença. ${ }^{17} \mathrm{Em}$ contrapartida, intercâmbios textuais entre a América portuguesa e a América hispânica no final do século XIX e início do século XX ocorreram em um contexto de relativa igualdade de relações de poder e de proximidade linguística. Nos termos utilizados no campo da literatura mundial, foram intercâmbios entre culturas periféricas, que pertenciam à mesma região geocultural, movimentos no subsistema periférico, em vez de entre o centro e a periferia. ${ }^{18}$ Aos olhos dos literatos brasileiros e argentinos, não parece haver uma clara hierarquia de prestígio entre a língua e a literatura espanholas e a língua e a literatura portuguesas do novo mundo, como a que existiu entre cada uma delas e a língua e a literatura francesas. Esse senso de relativa igualdade no grau do que Pascale Casanova chamou de "literariedade" em relação uma à outra, e da inferioridade compartilhada em relação ao centro europeu, podem ser a razão de duas outras características especiais dos intercâmbios interlinguais a serem discutidos aqui. ${ }^{19}$ Em termos de forma, são traduções relativamente curtas ou fragmentadas, em vez de obras integrais: frases isoladas, passagens curtas, e, às vezes, artigos inteiros ou ensaios que foram 
publicados principalmente pela imprensa periódica. E em termos de gênero, a maioria das traduções são obras não-ficcionais sobre assuntos históricos, políticos, econômicos e literários. $^{20}$

O aspecto singular do corpus de traduções ressaltado neste ensaio é a sua conexão a duas dimensões interligadas da integração sulamericana: relações internacionais e modernidade. A ligação entre tradução e relações internacionais - as quais também são, inerentemente, relações Eu-Outro e um lugar privilegiado para a formação das identidades coletivas $^{21}$ - adquire várias formas, às vezes concomitantemente, mas nem sempre. Primeiro, as traduções que serão discutidas aqui aparecem em momentos chave da relação entre Argentina e Brasil. Segundo, os assuntos tratados nos textos fontes são frequentemente ligados a um passado, presente ou futuro comum a ambos os países. Terceiro, tanto os autores quanto os tradutores são frequentemente estadistas ou literatos envolvidos na política externa, formal ou informalmente, como profissionais ou como comentaristas.

Esses tradutores ocasionais e as traduções por eles produzidas estavam profundamente incorporados ao advento da modernidade ("civilização", ou "progresso", na linguagem 140 contemporânea dos textos sul-americanos) no mundo Atlântico, no duplo sentido de "um projeto e ideologia da elite" e de "um modo de vida" massificado, compreendendo mudanças socioculturais e inovações tecnológicas reconhecíveis, especialmente a modernização e expansão da imprensa e a importância crescente da opinião pública. ${ }^{22}$ Como Hilda Sabato observa, na época, na maior parte dos países da América Latina, "a constelação de ideias e projetos que circularam entre as elites no poder favoreciam a 'publicidade' e consideravam a imprensa e as associações como a encarnação da sua estimada 'opinião pública'". ${ }^{23}$ Ángel Rama destacou a expansão simultânea do que ele chamou de ciudad letrada, ou seja, o número crescente dos literatos da América Latina urbana, os letrados, e a diversificação de suas atividades, com muitos deles encontrando seu espaço em profissões em rápida expansão, ligadas à diplomacia e ao jornalismo. ${ }^{24}$ Como resultado, a antiga diplomacia ministerial estava desaparecendo diante da ampliação da esfera pública. A prática e o pensamento sobre as relações internacionais por meio da tradução se tornaram uma parte integral da espessa rede de transferência textual transnacional e de fluxo intelectual que eram, ao mesmo tempo, formais e informais, privados e públicos, institucionais e não institucionais, e frequentemente conectados ao Estado-Nação, embora não necessariamente formados ou controlados por ele. 
No intuito de exemplificar esses desdobramentos interligados, passo a discutir alguns pontos importantes da tradução, modernidade e relações internacionais da América do Sul em ordem cronológica, com ênfase especial na coexistência da tradução e da não tradução na imprensa de Buenos Aires e do Rio de Janeiro. Lançando luz sobre esses "eventos" ou "cenas da tradução" amplamente esquecidos, refletirei sobre o que significou traduzir, ou não traduzir, em circunstâncias de contiguidade linguística, de crescente movimento de pessoas e informações através das fronteiras nacionais e de convergência de interesses e visões de progresso regional. ${ }^{25}$ Finalmente, argumentarei que a lógica inerente a esses embaraços transnacionais refletiram um espaço regional e ao mesmo tempo contribuíram para sua construção.

\section{Combatendo a Guerra da Tríplice Aliança por meio da tradução}

Nosso ponto de partida é a Guerra do Paraguai (1864-1870), também conhecida como Guerra da Tríplice Aliança, ainda outro episódio em uma longa história de conflitos armados portugueses, e mais tarde brasileiros, com hispano-americanos pelo controle do sistema do Rio da Prata. Desta vez, contudo, o Império lutou ao lado de seus rivais tradicionais, Argentina e Uruguai, contra o Paraguai, que acabou sendo derrotado. A natureza sangrenta e prolongada da luta, que dizimou cerca de dois terços da população do Paraguai, não impediu os governos eurocêntricos do Brasil e da Argentina de apresentarem-na como um embate entre a civilização e a barbárie com o objetivo de libertar a população paraguaia do governo tirânico de seu ditador, Francisco Solano López.

Portanto, a criação da Tríplice Aliança impactou não apenas o sistema de relações internacionais da América do Sul, mas também imagens e conceitos geo-culturais mútuos dos envolvidos. A cooperação luso-hispano-americana sem precedentes foi uma questão controversa no Brasil e na Argentina desde o princípio. Ela gerou polêmicas enraizadas, em grande escala, em rivalidades pessoais, políticas e ideológicas em cada país, mas transcendeu as esferas nacionais em termos de como foram conduzidos e de seus temas. A natureza multinacional do conflito significou que ambos, oponentes e partidários da aliança, basearamse em evidências de além das fronteiras nacionais e linguísticas para construir seus argumentos, algumas vezes também tentando atrair públicos estrangeiros. Nesse contexto, a tradução se tornou uma importante ferramenta na criação concomitante de alteridade e semelhança, identidades regionais e nacionais. ${ }^{26}$ 
$\mathrm{Na}$ Argentina, a crítica veio de um grupo de escritores de tendências populistas, nativistas e federalistas, o qual Nicolas Shumawy rotulou como "nacionalista". Shumway e outros estudiosos traçaram duas tendências nos escritos desses intelectuais durante a década de 1860 que se desenvolveram em conexão com as mudanças históricas nas relações entre Argentina e Brasil. A primeira tendência foi a ênfase crescente na definição cultural ou espiritual da nação. A segunda tendência, aparentemente oposta, foi a identificação com outros países da América hispânica e o discurso de americanismo. ${ }^{27}$ Em outras palavras, a nova rodada do expansionismo brasileiro no Rio da Prata, desta vez com o consentimento da Argentina, criou um estímulo duplo e simultâneo de identificação estatal e regional no qual o Brasil serviu como ponto de referência negativo.

O discurso rioplatense anti-brasileiro teve seu ápice em 1869, quando a prolongada batalha no Paraguai estava chegando ao seu sombrio fim. Naquele ano surgiu uma polêmica na imprensa de Buenos Aires entre Bartolomé Mitre - um estadista e literato que, como presidente da República Argentina de 1862 a 1868, levou-a à aliança com o Império Brasileiro - e o jornalista uruguaio Juan Carlos Gómez. Ambos os lados chamaram a atenção de seus leitores 142 de fala espanhola para a “A convenção de 20 de fevereiro", uma coleção de discursos proferidos no senado brasileiro por José Maria da Silva Paranhos, a qual constituía um relato apologético de sua missão diplomática na Argentina e no Paraguai em 1864, acompanhada de inúmeros documentos, oficiais ou não, de todos os quatro países envolvidos na guerra, reproduzidos em português como prova. ${ }^{28}$ Mitre teve vários longos encontros com este proeminente estadista brasileiro em Buenos Aires à época, com o qual manteve correspondência após esse período. "Leí con todo interés la brillante defensa parlamentaria que hizo", escreveu a Paranhos da linha de frente em setembro de 1865, solicitando cópias avulsas de seus discursos. Paranhos atendeu ao pedido, porém a remessa nunca chegou às mãos de Mitre. ${ }^{29}$ Não obstante, em 1869 Mitre foi capaz de citar dois parágrafos de $A$ convenção, provavelmente retirados de uma das duas cópias listadas no catálogo de sua biblioteca pessoal". ${ }^{30}$ As citações foram traduzidas do português para o espanhol de acordo com a natureza polêmica do texto-alvo. Afinal, entra-se num debate com o propósito de derrotar seu oponente, e, no intuito ter vantagens, Mitre teve que aumentar a legibilidade de sua evidência importada.

Curiosamente, Gómez, apesar de sua ardente oposição à Aliança, também se referiu a Paranhos como uma fonte confiável. Não houve insultos pessoais, o que pode atestar uma proximidade cultural entre as elites da região. Ainda assim, as relações entre as repúblicas do 
Rio da Prata e "a monarquia do Brasil" eram uma questão muito diferente do ponto de vista de Gómez. O Brasil sempre foi "la monarquía brasileña", uma entidade estranha e hostil aos seus vizinhos republicanos. Nós fomos responsáveis por "o martírio" do povo paraguaio, declarou Gómez, já que em vez de encararem a república dos povos do Prata, simbolizando a revolução, os paraguaios enfrentaram a monarquia brasileira, simbolizando a dominação estrangeira. ${ }^{31}$

A obstinada exclusão de Gómez do Brasil, por causa de seu regime monárquico e do legado intervencionista no Rio da Prata, despertou algumas reações além da de Mitre. Logo no início da disputa entre o argentino e o uruguaio, uma terceira voz interveio no debate, introduzindo uma postura conciliatória. Foi o diplomata e escritor José Mármol, exilado em Montevidéu e no Rio de Janeiro durante a década de 1840 e participante ativo da vida literária de ambas as cidades. Em 1846, em um artigo intitulado "Juventude progressista do Rio de Janeiro", publicado em português em uma revista literária do Rio, ele delineou uma visão de dimensões binacionais, regionais e continentais.

"Passai os olhos sobre uma carta da América", escreveu, "e encontrareis, é verdade, os limites acidentais que dividem um território de outro; porem passai outra vista d'olhos sobre o mapa moral das ideias, e dizei-me onde estão os limites bem marcados dos povos americanos, especialmente de nossa América meridional? Não, não achareis se não duas imensas classes que se disputam vigorosamente o predomínio: o povo tradicional da metrópole, isto é, o povo bárbaro, instrumento do despotismo, e o povo da revolução, isto é, o povo civilizado, garantia da liberdade." 32

Traços dessa visão estavam claramente presentes na intervenção de Mármol no debate de 1869, no qual ele exigiu uma "Política de unión, de confederación, de reconstrucción. No para hostilizar la autonomía monárquica del Brasil, sino para defender la autonomía republicana de nosotros mismos." O Brasil, com seus interesses de país americano e fronteiriço, pode se tornar um parceiro na realização de uma grande ideia, de uma "inmensa revolución en la existencia y en el porvenir de esta región de América." A unidade platina detém a chave para a interferência tradicional do Brasil nos assuntos de seus vizinhos, que havia sido encorajada pelo ódio interminável, pelo derramamento de sangue e pela corrupção característicos desse "obscuro laberinto de los pequeños estados" ao sul dela. Além disso, o povo brasileiro não deve ser confundido com seus antigos partidos governantes. Há uma nova geração no Império, ansiosa para deixar para trás a história das guerras no Rio da Prata. ${ }^{33}$ 
Neste último ponto, Mármol abordou uma tendência importante na política brasileira da época que tem sido amplamente documentada pela historiografia moderna, ainda que raramente explorada no contexto das relações internacionais sul-americanas, das trocas culturais transnacionais e da modernidade. Como é sabido, o final da década de 1860 viu uma crescente insatisfação com a estrutura de governo existente. Novos e velhos atores políticos criaram organizações únicas dentro e fora do parlamento que pressionavam por reformas com três objetivos principais: "minar as estruturas de poder que apoiavam as oligarquias tradicionais, reduzir a interferência do governo no setor privado e aumentar a autonomia das províncias". ${ }^{34}$ O consenso é que esta agenda respondeu principalmente aos interesses e expectativas dos crescentes setores médios urbanos, determinadas elites regionais e facções reformistas dentro das forças armadas. Ao mesmo tempo, além das circunstâncias domésticas, o objetivo abrangente de modernização material e progresso comum aos apoiadores da reforma no Brasil também foi atribuído à influência dos desenvolvimentos materiais e culturais no Atlântico Norte. $^{35}$

A intervenção de Mármol na polêmica de Mitre-López, no entanto, sugere um

144 enquadramento espacial diferente. O terceiro polemista não foi apenas um observador externo da mudança do clima político no Brasil, mas uma parte integrante dela como diplomata e escritor. Mármol, que retornou ao Rio de Janeiro em 1865, desta vez não como exilado, mas como ministro da Argentina, integrou seu conhecimento direto do Império e sua diplomacia na polêmica. Desta forma, juntou-se a outros escritores-estadistas argentinos, uruguaios e brasileiros como Mitre, Gómez e Paranhos, que através de suas movimentações entre as capitais, encontros, correspondências e escritos públicos do sul da América do Sul teceram uma discussão transnacional sobre a Guerra do Paraguai e suas consequências para a região como um todo. Mas foram os brasileiros do supracitado campo reformista que transformaram ativamente o debate Platino em um caso luso-hispano-americano pleno, empregando a tradução como um instrumento crucial.

\section{A Guerra da Tríplice Aliança por meio da tradução: a entrada dos brasileiros}

Em 24 de dezembro de 1869, o jornal carioca A Reforma publicou em uma de suas páginas internas, sob o título "Notícias do exterior", uma tradução completa da primeira carta de Mitre respondendo a Gómez, escrita apenas duas semanas antes. Uma nota introdutória muito curta precedeu o texto, elogiando o ex-presidente da Argentina por fazer justiça àqueles 
que lutaram ao seu lado na campanha contra o Paraguai. Tanto a introdução como a tradução eram anônimas. ${ }^{36}$ Então, em 11 de janeiro, seguiu-se outra tradução de uma carta de resposta pública de Mitre, desta vez cobrindo toda a primeira página, precedida por um prefácio significativo. $\mathrm{O}$ autor do prefácio foi Francisco Otaviano, o homem que negociou e assinou o tratado com a Argentina e o Uruguai em Buenos Aires em maio de 1865, como ministro brasileiro plenipotenciário para assuntos da Tríplice Aliança. Otaviano foi um dos vários "liberais históricos" - como eram chamados os membros do antigo Partido Liberal, extinto desde 1862 - que entre 1868 e 1869 se uniram a um novo grupo de liberais para formar o Clube da Reforma e um novo Partido Liberal, cuja crítica ao regime beirava o republicanismo. $A$ Reforma foi lançada em 1869 como porta-voz do novo Partido Liberal, com Otaviano como editor, transformando-se em "o jornal mais prestigioso da época". 37

Em seu prefácio, Otaviano entrelaçou a política externa brasileira com a política interna brasileira, as relações internacionais sul-americanas com as visões sul-americanas de ordem e progresso. Intitulado "A Aliança", o paratexto começou com uma questão diferente: o novo status da Argentina como modelo para os reformistas brasileiros. "Irritam-se os nossos adversarios," declarou Otaviano, "quando lhes apontamos como exemplo as boas práticas da administração e da política de Buenos Aires, que sem grande esforço atraem para lá os braços europeus, e fazem convergir capitais estrangeiros para as indústrias daquela nacionalidade vivaz." Otaviano admitiu que os argentinos ainda tinham um longo caminho a percorrer para se tornarem "um povo bem organizado". Contudo, o atual estado de coisas não era culpa de Buenos Aires, cujos líderes estavam fazendo tudo ao seu alcance para trazer civilização e liberdade às remotas províncias da federação. ${ }^{38}$

Em algumas linhas preliminares, Otaviano introduz na cena política brasileira um tema central da tradição intelectual argentina - a luta entre a cidade e o campo, a civilização e a barbárie $^{39}$ - infundindo no texto original um significado ideológico que transcende em muito o tema original da Guerra do Paraguai. Há um aparente vínculo, ainda que parcialmente negado, do debate argentino sobre a Aliança com a crescente tensão entre novos liberais e conservadores no Brasil e das disputas internas nacionais em ambos os países com o futuro da região como um todo. Segundo Otaviano, existem duas Argentinas, a Argentina de Buenos Aires, que é representada pelo comando "tolerante, moderado, sem caprichos, e ao mesmo tempo ilustrado e firme" de Mitre, e a Argentina de "essas regiões semifeudais." E foi a Argentina de Buenos Aires que reconheceu a necessidade de "duas nações limítrofes, civilizadas, com igual interesse 
na livre navegação do Paraná," para alcançar o entendimento mútuo que poderia eventualmente trazer "paz e desenvolvimento político para a América do Sul." 40

A Reforma continuou a publicar longas traduções anônimas da parte de Mitre no debate, bem como intervenções de seu aliado próximo e ex-ministro de Relações Exteriores, Rufino de Elizalde, no decorrer de janeiro de 1870, expandindo ainda mais os limites da controvérsia da guerra em termos de conteúdo, idioma e distribuição. Essa expansão, vale notar, não foi unidirecional - do espanhol para o português, de Buenos Aires para o Rio de Janeiro -, como a maioria dos movimentos explorados nos Estudos de Tradução, mas sim multidirecional e multidimensional. Como já mencionado, as cartas públicas de Mitre e Gómez continham referências e uma tradução de um texto brasileiro de Paranhos, que havia viajado para Montevidéu e Buenos Aires antes de escrevê-lo, onde estabeleceu contato pessoal com Mitre. O mesmo aconteceu com Otaviano, que, como editor d'A Reforma, era responsável pela importação e tradução dos textos de Mitre. As trajetórias de vida de Gómez e Mármol foram profundamente macrorregionais, abrangendo jornadas diplomáticas e jornalísticas através da fronteira de seus países nativos que alimentavam seus escritos de maneira direta e indireta.

146 A Guerra da Tríplice Aliança trouxe em seu rastro um acúmulo de tráfego entrecruzado de pessoas e textos entre o Rio de Janeiro, Buenos Aires, Montevidéu e outros pontos no sul da América do Sul, que começaram a corroer conceitos, ideias e identidades profundamente enraizados. A abordagem histoire croisée nos alerta para o fato de que algo ocorre nesse tipo de processo de cruzamento e para a sua importância. "Atravessar também é entrecruzar, entrelaçar, isto é, atravessar várias vezes em um ritmo que pode ser assombroso, [... o que] aponta para uma análise de resistências, inércias, modificações - em trajetória, forma e conteúdo - e novas combinações que podem tanto resultar do processo de cruzamento quanto se desenvolver nele. Tais transformações, além disso, não estão necessariamente limitadas a elementos em contato: também podem afetar seu ambiente local ou remoto e se manifestar em um momento posterior." 41

$\mathrm{O}$ processo de cruzamento que nos interessa aqui foi, de fato, assim: rápido, intenso e multidirecional, com efeitos claros e significativos nos lados em contato e além. Tudo isso é ainda mais evidente em duas intervenções adicionais no debate Mitre-López, que originalmente havia sido publicado em espanhol na imprensa de Buenos Aires e que A Reforma reproduziu em uma versão em português no final de janeiro. Significativamente, desta vez os autores eram brasileiros que, ao contrário de Otaviano, não comentaram sobre o debate de fora e de longe,

PREUSS. "Povos quase da mesma língua": não-/tradução, modernização, e as relações Brasil-Argentina, 18651900

Belas Infiéis, v. 8, n. 2, pp. 135-164, 2019. DOI: 10.26512/belasinfieis.v8.n2.2019.24385 
mas inseriram-se nele de muito perto. Estes eram Quintino Bocaiúva e Francisco Xavier da Cunha, que foram para o Rio da Prata durante os últimos estágios da Guerra do Paraguai, e cujas vidas se entrelaçaram com o advento da modernidade no Atlântico Sul-ocidental.

Bocaiúva (1836-1912), cuja mãe, nascida em Buenos Aires, era filha de pai espanhol imigrado para o Rio de Janeiro e de mãe uruguaia, já era um renomado jornalista com experiência em empresas internacionais que confirmam seu espírito liberal e modernizador. Ele se envolveu na construção de um cabo telegráfico subaquático, apoiado por investimentos norte-americanos, e na fundação da Sociedade Imperial de Imigração, em cooperação com um capitalista cubano representante de uma empresa de navegação a vapor que se deslocava entre os Estados Unidos e o Brasil. Entre 1866 e 1867, Bocaiúva residiu em Nova York, onde chefiou a filial local da Sociedade da Imigração. Em 1868, chegou a Montevidéu para seguir sua vocação como jornalista, ou para ir em busca de interesses comerciais, mas isto não está totalmente claro. ${ }^{42}$

Cunha, ex-proprietário de uma revista liberal em sua província natal no Rio Grande do Sul e ex-militar, chegou dos campos de batalha do Paraguai à capital uruguaia no ano seguinte e tornou-se amigo íntimo de seu compatriota. Em suas memórias, escritas cerca de 40 anos depois, Cunha conta como Bocaiúva e ele viajavam com frequência pelo rio até Buenos Aires, onde passavam dias na companhia de velhos e jovens intelectuais locais, entre eles Héctor Varela. ${ }^{43}$ Este último, com quem a relação dos dois brasileiros tinha sido especialmente próxima, era o editor do La Tribuna (1853-1884), por muitos anos o jornal mais vendido da Argentina, que publicou os polêmicos artigos de Mitre e Gómez.

Esse contexto é essencial para compreender a publicação de duas cartas públicas de Bocaiúva e Cunha em espanhol no La Tribuna como resposta declarada à posição anti-Aliança de Gómez, cartas que foram republicadas na íntegra em português por A Reforma em $1^{\circ}$ de janeiro. Bocaiúva dirigiu sua carta pessoalmente a Varela, referindo-se a ele como "Mi querido amigo", mencionando como o debate chegou ao seu conhecimento por meio de sua reprodução pelo jornal El Telégrafo Marítimo de Montevidéu. Cunha sentiu-se "autorizado" a se dirigir diretamente a Gómez com base na convivência entre eles, ainda que breve, como declarou no início de sua carta ${ }^{44}$ - outra prova da integração social e intelectual simultânea de brasileiros com mentalidade reformista nas esferas públicas conectadas das duas capitais Platinas.

Essa integração tangível surgiu com um desdobramento ideológico análogo que já era aparente em Otaviano, mas adquiriu uma forma mais radical com os dois migrantes que em 
breve emergiriam, ao voltarem para casa no final daquele ano, como figuras-chave na origem do republicanismo brasileiro. Repleta de um espírito e terminologia americanistas, a refutação de Bocaiúva à posição de Gómez aclamava a Aliança como um divisor de águas histórico cuja importância transcendia quaisquer cálculos de vantagem militar, ganhos territoriais, defesa da honra e mesmo a conquista da liberdade de um povo oprimido. $\mathrm{O}$ verdadeiro significado da Aliança está em "el hecho moral de la afianza, la aproximación de tres pueblos que deben ser hermanos y amigos"; povos, não governos. Não obstante, a dolorosa perda de tantas vidas e suas terríveis consequências, a vitória sobre o Paraguai "serviría y servirá para fortificar en esta parte de nuestro continente los principios de la única política que me parece garantizar las grandes conquistas de la libertad, de la democracia y de la fraternidad americana." ${ }^{45}$

Em qual idioma essas palavras foram originalmente escritas? Foi o espanhol platino que o escritor brasileiro ouviu de sua mãe? Ou o português, traduzido para o espanhol para publicação? Disto não podemos ter certeza, na ausência de qualquer referência explícita ao aspecto linguístico por parte dos envolvidos e dada à aparente capacidade bilíngue de Bocaiúva, sugerida por evidências circunstanciais de sua permanência no Rio da Prata. A tradução

148 provavelmente aconteceu, mas sem qualquer indicação clara da língua de partida. O que é certo é que vários textos polêmicos inter-relacionados de cidadãos das três nações sul-americanas circularam entre as cidades de Buenos Aires, Montevidéu e Rio de Janeiro, disponíveis para leitores de jornais em espanhol e português, produzindo e reproduzindo, portanto, um espaço sócio-político-cultural.

\section{“con ligerísimas diferencias, la misma lengua:” la fiesta literaria/a festa literaria de 1883}

Essa tendência de conectividade encontrou uma manifestação mais institucionalizada em "A festa literária por ocasião de fundar-se na capital do império a Associação dos Homens de Letras do Brasil”, realizada no Liceu de Artes e Ofícios do Rio de Janeiro em 30 de agosto de 1883. Estavam presentes o Imperador Dom Pedro II, juntamente com a herdeira imperial e Princesa Regente Isabel, bem como diversos escritores, jornalistas, políticos de alto e baixo escalão, militares e dois cavalheiros argentinos, Vicente G. Quesada e seu filho Ernesto Quesada. De acordo com o programa oficial, a celebração foi realizada em homenagem aos dois intelectuais estrangeiros que foram incluídos entre os palestrantes. Vários dias antes, um convite dos cinco membros do comitê organizador para Ernesto Quesada circulou na imprensa do Rio de Janeiro, dizendo: "Son conocidos en esta capital los servicios prestados por V. y su 
digno padre el señor doctor Vicente G. Quesada, como escritores, a fin de combatir, por lo que toca a las bellas letras, el aislamiento en la América Latina." 46

Os Quesadas estiveram de fato envolvidos como autores e editores em uma empresa transnacional desse tipo nas duas décadas precedentes. Em 1861, o pai havia lançado a Revista del Paraná, uma revista dedicada à história, literatura, direito e economia política, não só da Argentina, mas também da América, com o duplo objetivo de promover o autoconhecimento nacional e uma maior consciência dos desenvolvimentos intelectuais entre as outras repúblicas hispano-americanas. ${ }^{47}$ Dois anos depois, outro periódico sucedeu-a: La revista de Buenos Aires. Historia americana, literatura, derecho y variedades. Periódico destinado a la República Argentina, la oriental del Uruguay y la del Paraguay (1863-1871). Desta vez, a agenda transhispano-americana foi muito mais pronunciada. A declaração de abertura mencionava a revista chilena, Revista del Pacífico (1858-1861), e a peruana, La Revista de Lima (1859-1863), como modelos para imitação, saudando "aquellos preciosos santuarios consagrados a las letras americanas en territorios unidos a la distancia con nuestro por esfuerzos y tendencias comunes que el Pacífico y los Andes no son bastantes a dividir." 48

Finalmente, em 1881, os dois Quesadas iniciaram a Nueva Revista de Buenos Aires [NRBA] (1881-1885), que estava mais orientada para o presente do que suas duas predecessoras, que "se mantuvieron deliberadamente alejadas de todo interés de actualidad y servían únicamente como repertorio de la antigua historia americana." Esta reorientação respondeu a "las necesidades de una sociedad que marcha sin cesar, buscando en la consolidación de la paz, las verdaderas y positivas garantías políticas y civiles de la vida culta y libre." Em outras palavras, enquanto as revistas das décadas de 1860 a 1870 refletiam a busca do autoconhecimento desinteressado, nacional e continental, a $N R B A$ sinalizou uma fusão consciente dos campos material, intelectual e político e, mais especificamente, da modernização, da história internacional e da diplomacia contemporânea, mantendo e até fortalecendo as inclinações macrorregionais de suas antecessoras. O objetivo final declarado de publicar pesquisas sobre as relações internacionais americanas era, segundo Quesada pai, promover a paz como base para a liberdade e a prosperidade. ${ }^{49}$

Foi a partir dessas origens e reputação transnacionais que os Quesadas chegaram ao Rio de Janeiro, o pai na qualidade dupla de empresário cultural e de diplomata, após ser nomeado ministro argentino no Brasil. Na Fiesta literária, pai e filho mantiveram-se fiéis à sua declarada crença na aproximação cultural e política entre a República Argentina e o Império do Brasil

PREUSS. "Povos quase da mesma língua”: não-/tradução, modernização, e as relações Brasil-Argentina, 18651900

Belas Infiéis, v. 8, n. 2, pp. 135-164, 2019. DOI: 10.26512/belasinfieis.v8.n2.2019.24385 
como parte de uma tendência macrorregional mais ampla: "Las naciones de la América Latina", disse Ernesto Quesada em seu discurso,

\begin{abstract}
tanto las de origen español como lusitano, pertenecen, puede decirse, a la misma raza, y tienen, con ligerísimas diferencias, la misma lengua, religión y costumbres; Son, además, limítrofes, y tienen idénticos problemas que resolver, disponen de medios similares y su porvenir es análogo. Con todo, viven en un aislamiento intelectual y material que causa asombro [...] Este estado de cosas constituye un verdadero crimen de leso americanismo. Los hombres de corazón de todas las secciones latino-americanas deben aunar sus esfuerzos, y tratar, por todos los medios a su alcance, de modificar semejante situación. ${ }^{50}$
\end{abstract}

Enquanto os escritos dos Quesadas não refletiam diretamente sobre o papel da tradução em si mesma no seu projeto de integração binacional e continental, eles usaram a tradução como um meio para mudar a realidade de mútua ignorância luso-hispano-americana. O terceiro volume da NRBA apresentou um artigo expandido do eminente crítico literário brasileiro Silvio Romero, traduzido para o espanhol a partir do original em português, publicado anteriormente em 1879 na Revista Brasileira ${ }^{51}$. Depois disso, a NRBA continuou a publicar outras traduções a partir do português, incluindo discursos proferidos na referida festa literária ao lado de reportagens publicadas em jornais sobre o evento. ${ }^{52}$ Curiosamente, os Quesadas escolheram traduzir aqueles textos apesar de o jovem Quesada considerar o português e o espanhol como quase a mesma língua, e a despeito do uso intercambiável de ambas as línguas durante a celebração literária, em aparente contradição com a sua ideologia linguística e a prática de intercâmbios bilíngues.

Os Quesadas também estavam envolvidos com a tradução no sentido inverso. Em setembro de 1883, pouco tempo após sua participação na festa literária, a Gazeta de Notícias do Rio imprimiu, em sua primeira página, uma tradução para o português das impressões de viagem pela capital do Brasil por Ernesto Quesada, que foi publicada quase simultaneamente em espanhol na NRBA. ${ }^{53}$ Conforme as memórias de Vicente Quesada, aquelas notas de viagem tinham sido redigidas a pedido dele, como parte de seu "plan diplomático y para granjearme las simpatías de los políticos y de los hombres de sociedad." ${ }^{54}$ Entretanto, sua publicação na Gazeta de Notícias guardava a promessa de um público mais amplo e popular. A Gazeta representava uma nova imprensa, diferente dos jornais partidários tais como A Reforma, o qual começara a promover a reconciliação com a Argentina e o americanismo cerca de uma década antes. Lançado em 1874, foi o jornal diário mais vendido no Brasil, o primeiro entre diversos jornais comerciais apartidários que surgiram principalmente no Rio de Janeiro em conexão com 
a modernização da cidade, expandindo rapidamente o público leitor e favorecendo o surgimento da cultura de massa, de maneira semelhante ao que aconteceu em Buenos Aires. Na década de 1870, ambas as capitais argentina e brasileira experimentaram o advento do jornalismo moderno do final do século XIX, caracterizado pela centralidade da informação, pela compartimentalização dos conteúdos e pela renovação gráfica. ${ }^{55}$ Além disso, novos jornais que se juntaram à Gazeta de Notícias, tais como os cariocas $O$ Globo (1876) e O País (1878), ambos sob direção de Quintino Bocaiúva, e os portenhos La Prensa (1869) e La Nación (fundado por Bartolomé Mitre em 1870), também eram altamente transnacionais, apresentando crônicas de correspondentes estrangeiros e seções de notícias internacionais com base no telégrafo. A emergência do Rio da Prata durante a década de 1870, não somente como "um ponto chave nodal para a economia mundial" mas também como "um ponto focal no sistema de comunicação mundial", desempenhou um papel crucial na criação de uma esfera pública do Atlântico Sul. Reuteurs e Havas, as duas maiores agências de notícias globais, abriram escritórios conjuntos em Recife, Bahia, Rio, Montevideo e Buenos Aires já em 1875, trazendo assim leitores urbanos ao longo da costa atlântica da América do Sul para cada vez mais perto não apenas de Paris, Londres e Nova Iorque, como se discute frequentemente, mas também uns dos outros. ${ }^{56}$

\section{Celebrando a abolição e a "ordem e progresso" por meio da tradução}

Este novo patamar de religación regional, que significou aceleração e ampliação de transferências textuais e tradução, manifestou-se no contexto de outro momento-chave na história da modernidade sul-americana e das relações internacionais: a abolição da escravidão no Brasil em 1888 e a queda da monarquia brasileira em 1889. O período subsequente à Guerra do Paraguai testemunhou um desgaste adicional da autoimagem de superioridade insular arrogante do Brasil em relação aos seus vizinhos, já que muitas partes da América hispânica alcançaram níveis de estabilidade política e crescimento econômico sem precedentes, principalmente na Argentina, que também havia começado a experimentar uma entrada maciça de imigrantes europeus. Estereótipos negativos profundamente arraigados de autoritarismo crônico, desordem política e atraso material não desapareceram imediatamente, no entanto mais e mais brasileiros sentiam que seus vizinhos estavam progredindo, enquanto o Brasil estava estagnado. Sentimentos de inferioridade começaram a se desenvolver, agravados pela condenação, pela América Hispânica, da sociedade escravocrata brasileira, da miscigenação

PREUSS. “Povos quase da mesma língua”: não-/tradução, modernização, e as relações Brasil-Argentina, 18651900

Belas Infiéis, v. 8, n. 2, pp. 135-164, 2019. DOI: 10.26512/belasinfieis.v8.n2.2019.24385 
racial e do sistema político monárquico. Como resultado, houve uma demanda crescente para reverter a velha política agressiva em relação ao Rio da Prata, como um prelúdio para o Brasil se tornar parte de uma nova América do Sul que havia entrado na era liberal-conservadora de ordem e progresso. Bocaiúva e outros líderes republicanos expressaram esta visão muito claramente em seu famoso manifesto fundador de 1870, como fizeram notáveis abolicionistas durante a década de 1880. O sucesso desses dois movimentos reformistas, o abolicionismo e o republicanismo - eles próprios uma parte inerente da modernidade -, em alcançar seus objetivos no período de menos de dois anos removeu as barreiras para uma consciência mais profunda das aspirações de reaproximação argentino-brasileira e de unidade sul-americana expressas por estadistas e intelectuais de ambos os lados desde a década de $1860 .{ }^{57}$

Este contexto pode explicar por que a abolição da escravatura no Brasil em 13 de maio de 1888 tornou-se um assunto regional transnacional. Jornais em diversas capitais sulamericanas relataram o ato em termos altamente favoráveis, descrevendo-o como uma vitória para o Brasil, bem como para o princípio de liberdade para a América. Em Assunção, e ainda mais em Santiago do Chile, houve atos de tributo públicos. ${ }^{58}$ No entanto, nada igualou a

152 magnitude da reação na Argentina. Em 17 de maio, declarado feriado nacional pelo governo argentino, uma multidão de 40 mil pessoas marchou pelas ruas decoradas de Buenos Aires em uma manifestação de apoio em massa. Liderando o desfile estava o ex-presidente Bartolomé Mitre que, com a chegada da manifestação à missão diplomática brasileira, dirigiu-se à multidão.

Em seu discurso público, Mitre ressaltou a grande contribuição da Guerra do Paraguai para erradicar o estigma da escravidão da imagem do Brasil. Para apoiar essa afirmação histórica, ele citou a defesa da Lei do Ventre Livre diante do Parlamento brasileiro, em 1871, por José Maria da Silva Paranhos, que acabara de receber o título nobre de Visconde do Rio Branco. É mais uma vez Mitre, que mais uma vez cita frases traduzidas de um discurso parlamentar do mesmo estadista brasileiro por ele citado em tradução em um contexto similar de reaproximação argentino-brasileira duas décadas antes. Não é apenas a identidade dos indivíduos envolvidos e o contexto que deveriam ser destacados, mas também o conteúdo dos fragmentos traduzidos. Em 1871, Mitre disse ao seu público: “el ilustre ministro Paranhos, al sostener en el parlamento brasileño la ley de la libertad de vientres, confirmaba el pronóstico [...] que la alianza del imperio con las repúblicas del Plata, daría por resultado necesario la abolición de la esclavitud en el Brasil." Após esta introdução, ele inseriu as palavras de 
Paranhos transpostas para o espanhol: "Yo me he hallado a la terminación de la guerra del Paraguay entre cincuenta mil brasileños que estaban en contacto con los pueblos vecinos, y sé, por confesión de los más ilustrados de ellos, cuántas veces la institución odiosa de la esclavitud en el Brasil, nos vejaba y nos humillaba ante el extranjero." 59

Evidentemente, Mitre usou uma tradução fragmentada e não reconhecida para construir uma história argentino-brasileira entrelaçada, cimentando a identificação mútua no presente por meio da lembrança de encontros passados. Mas aqui novamente, como no caso da polêmica da Guerra do Paraguai, transferência de texto e tradução ocorreram em mais de uma direção. Depois que as palavras de Paranhos ressoaram em espanhol no espaço público da capital da Argentina, com o claro objetivo de melhorar as relações com o Brasil, elas instantaneamente regressaram ao Rio de Janeiro. No dia seguinte, a Gazeta de Notícias publicou o discurso de Mitre na íntegra em sua seção de telegramas, abaixo de uma descrição do desfile de Buenos Aires no presente do indicativo, indicando a data e a hora, aumentando a sensação de uma experiência compartilhada em um espaço comum. ${ }^{60}$

Um ano e meio depois, um dos primeiros atos do recém-instalado regime republicano no Brasil foi a rápida solução de uma antiga disputa fronteiriça com a Argentina sobre o território de Missões como parte de uma americanização geral da política externa brasileira em nome da solidariedade republicana do Novo Mundo. Com apenas um mês no cargo, o novo ministro das Relações Exteriores, Quintino Bocaiúva, viajou para Montevidéu para se reunir com seu homólogo argentino e assinar um tratado que dividia o território pela metade. De lá, Bocaiúva continuou sua jornada em direção ao Sul para celebrar o acordo em diversas cidades argentinas. Reportagens e artigos de jornais sobre o acordo publicados pela imprensa brasileira e argentina foram coletados e publicados em formato de livro pelo governo argentino, incluindo algumas traduções Português/Espanhol; entre elas, um discurso público do próprio Bocaiúva que se iniciava com um pedido de desculpas: "Desearía expresarme en vuestro propio idioma al contestar a las manifestaciones de cariño y simpatía con que me honráis, pero he de apelar a vuestra generosidad y en ella fio que me permitáis hacerlo en el mío." ${ }^{61}$ Como no caso do discurso dos Quesadas, em espanhol, na festa literária no Rio de Janeiro, Bocaiúva permitiu-se falar em português na esperança de ser entendido, mas seu discurso acabou traduzido na publicação impressa.

A aproximação brasileiro-argentina culminou com a troca de visitas presidenciais em 1899 e 1900, eventos celebrados com grande solenidade e ampla cobertura da imprensa nos 
espaços públicos do Rio de Janeiro e de Buenos Aires em processo de modernização. Até então, a capital argentina já havia experimentado significativas reformas haussmannianas, determinadas a refazê-la à imagem de Paris, naquilo que constituía uma "declaração dos governantes recém-triunfantes" do país, como de outras elites nacionais eurocêntricas em toda a América Latina, “de sua pretensão ao status 'moderno' para si e para suas pátrias”. Embora esse "exercício ideológico no planejamento urbano" ocorresse no Rio somente após as visitas, essa cidade já expressava o mesmo espírito triunfalista, mas com uma diferença. ${ }^{62}$

O duplo encontro foi uma celebração transnacional de virilidade, poder militar e prosperidade econômica; um espetáculo de Paz y Administracion, Ordem e Progresso, para empregar os lemas correspondentes dos governos argentino e brasileiro. No entanto, esse “ordem e progresso" não foi concebido ou apresentado como uma cópia exata de modelos externos, mas sim como algo em parte original, como uma modernidade em construção exclusivamente sul-americana ou latino-americana. Diversos dias antes da chegada do Presidente Roca ao Rio em agosto de 1899, o principal jurista brasileiro, autor da Constituição republicana de 1891, senador e editor de jornal, Rui Barbosa, publicou um artigo que 154 ovacionava a amizade em evolução entre dois povos "da mesma raça, da mesma religião, quase da mesma língua [...] aproximados pela contiguidade, pela história, pelo interesse americano." 63 Estas palavras foram importantes o bastante para conquistar a gratidão do Ministro argentino no Brasil, que em uma carta cheia de emoção para Rui, atribuiu ao encontro bilateral significado continental, definindo seu objetivo final como "la grandeza de América latina. ",64

Posteriormente, durante as duas visitas, Rui, como outras vozes oficiais e não-oficiais de ambos os lados, introduziu a noção de cooperação ativa entre o que ele nomeava "as três grandes nações da América meridional", colocando-a novamente em um discurso misto de geoestratégia, valores morais, história e etnia. Um processo de aproximação entre Argentina, Chile e Brasil começara graças a uma crescente consciência compartilhada de um interesse comum: “a preservação vivaz do contingente latino na evolução americana.” Assim reivindicou Rui no dia em que o couraçado argentino San Martín, transportando Roca, entrou na Baía de Guanabara acompanhado pelo cruzador Buenos Aires e o torpedeiro Patria. O presidente da Argentina, que antes de vir à capital brasileira encontrou-se com o seu homólogo chileno a bordo de um navio de guerra no estreito de Magalhães, conseguiu a aprovação de Rui "lançando as bases da paz meridional e da segurança Latina no continente de Colombo." ${ }^{\circ 5} \mathrm{O}$ Ministro 
brasileiro nos Estados Unidos declarou a mesma visão de cooperação "latina" ante o imperialismo norte-americano e/ou europeu, neste caso de maneira confidencial, propondo uma aliança de segurança econômica entre Brasil, Argentina, Chile e Uruguai, países que tinham todas as razões para cooperar por compartilharem a "mesma raça, mesma religião, quase a mesma língua."66

Como nos casos anteriores da festa literária de 1883, da fiesta de la libertad de 1888 e das comemorações do acordo de fronteira de 1890, nesta ocasião, publicações diárias e periódicas nos dois países também apresentaram diversos textos em espanhol e português lado a lado ou verdadeiramente interligados, criando assim um espaço comunicativo bilíngue. ${ }^{67}$ Foi neste contexto que o congressista Serzedelo Correia exprimiu suas ideias sobre as confluências ribeirinhas e linguísticas mencionadas no início deste artigo. Curiosamente, a despeito das professadas relações familiares e do entendimento mútuo entre os falantes do português brasileiro e do espanhol argentino, as visitas presidenciais também geraram muitas traduções em meio ao aumento da transferência transnacional de textos, sendo um deles o discurso do congressista. Declarando a inutilidade da tradução, ele apareceu, paradoxalmente, traduzido anonimamente para o espanhol no livro oficial das festividades, cujo título - El Brasil y la Argentina: confraternidad sud-americana - expressou tanto os ideais nacionais como os macrorregionais. ${ }^{68}$

\section{Considerações finais}

Em suma, vale a pena retornar à questão do porquê e do significado de todas essas traduções e não-traduções realizadas, como vimos, em um contexto de afinidade simbólica e comunicativa entre o espanhol e o português; do declarado empenho para reaproximação cultural e política; e de projetos concretos destinados a atingir este objetivo por meio de transferências transnacionais. Em seu importante estudo antropológico e sociológico Traducir el Brasil, Gustavo Sorá propõe considerar a tradução como "un observatorio para comprender la velada competición entre dos estados nacionales que, en busca de hegemonías regionales y continentales, parecen negar sus relaciones culturales en virtud del privilegio de su reconocimiento en los países 'centrales'." Consistente com esta linha de interpretação, o capítulo do livro de Sorá que cobre o período em que estamos nos concentrando, é, de modo significativo, intitulado "experimentos de alteridad" 69 . Sem negar este aspecto, gostaria de, em vez disto, enfatizar a dinâmica da identidade. É verdade que os atos tradutórios explorados neste 
artigo parecem ir contra a noção de apenas "ligerísimas diferencias" entre espanhol e português que deveriam ter tornado a tradução supérflua. Vistos desta perspectiva, os eventos tradutórios aqui estudados podem, de fato, ser interpretados como expressão e reforço da alteridade. Entretanto, também podem ser interpretados como complementares, e não somente como contraditórios, à identificação ideológica e à prática da não-tradução entre as duas línguas. Em primeiro lugar, na dimensão material, estes eventos tradutórios ocorreram em conjunto com o crescente movimento de homens e textos através das fronteiras nacionais na América do Sul. Em segundo lugar, na dimensão comunicativa, refletem um esforço para aumentar a inteligibilidade e a compreensão mútua. Em ambas as dimensões, eram, ao mesmo tempo, um produto e um instrumento da modernidade e das relações internacionais sul-americanas, da construção do espaço regional com base em elementos étnicos, experiências históricas, interesses políticos e horizontes ideológicos compartilhados.

Em seu Translation and Text Transfer, Anthony Pym propõe

definir os limites de uma cultura como pontos onde textos transferidos tiveram que ser (intra ou interlingualmente) traduzidos. Isto é, se um texto pode ser transferido adequadamente sem tradução, há continuidade cultural. E se um texto foi traduzido, representa a distância entre pelo menos duas culturas. Desta maneira, os Estudos de Tradução evitam ter que conectar todos os pontos de contiguidade do mesmo modo que as fronteiras políticas fazem. Afinal, não há razão óbvia para que os pontos de contato e as trocas entre culturas devam formar linhas contínuas. Cultura não é geopolítica. Transferência e tradução dizem respeito a situações de contato e troca, não a separações lineares. ${ }^{70}$

Se adicionarmos o adjetivo "nacional" depois de "cultura" para adequar estas reflexões ao nosso caso, descobrimos que ele não se enquadra perfeitamente na primeira parte do esquema inspirador de Pym, mas se encaixa na segunda.

O que a coexistência da tradução e da não-tradução português-espanhol entre a Argentina e o Brasil revela é antes a formação de algo novo no processo de travessia, algo que na verdade não tem limites claros, como rios que correm uns para os outros. ${ }^{71}$

\section{REFERÊNCIAS BIBLIOGRÁFICAS}

ALONSO, Angela. Idéias em Movimento: a Geração 1870 na Crise do Brasil-império. São Paulo, Paz e Terra, 2002.

AMANTE, Adriana. Poéticas y políticas del destierro: argentinos en Brasil en la época de Rosas. Buenos Aires. Fondo de Cultura Económica, 2010. 
ARGENTINA. Tratado de Misiones. Litigio solucionado. Las repúblicas brasilera y argentina. Homenajes al ministro brasilero Bocayuva en El Plata. Firma del tratado en Montevideo. Resumen general de las fiestas 1889-90. Buenos Aires: Sommaruga, 1890.

ASSIS BRASIL, Joaquim Francisco. Um diplomata da República. Rio de Janeiro: CHDD/FUNAG, 2006.

BARATTA, Victoria. La oposición a la Guerra del Paraguay en Buenos Aires - un análisis de las representaciones de la nación argentina en el periódico La América (1866). Revista Eletrônica da ANPHLAC, São Paulo, n. 13, pp. 83-108, 2012. Disponível em: http://revistas.fflch.usp.br/anphlac/article/view/1320/1188 Acesso: fevereiro 2019.

BASTIN, Georges L. Subjectivity and Rigor in Translation History: The Case of Latin America. In: BASTIN, Georges L. BANDIA, Paul F. Charting the Future of Translation History. Ottawa: University of Ottawa Press, 2006, pp. 111-129.

BASTIN, Georges; ITURRIZA, María Gabriela. La traducción como elemento creador de identidad en la prensa independentista de Venezuela (1808-1822). Trans - Revista de Traductología, Málaga, Espanha, n. 12, pp. 81-94, 2008. Disponível em: http://www.revistas.uma.es/index.php/trans/article/view/3130 Acesso: fevereiro 2019.

BURKE, Peter. Cultures of Translation in Early Modern Europe. In: BURKE, Peter. HSIA, R. Po-chia. (ed.) Cultural Translation in Early Modern Europe. Cambridge: Cambridge University Press, 2007, pp. 7-38.

CÂNDIDO, Antônio. Literature and Underdevelopment. In: CÂNDIDO, Antônio. On Literature and Society. Edited, translated and introduced by Howard S. Becker. Princeton: Princeton University Press, 1995, pp. 127-130.

CASANOVA, Pascale. The World Republic of Letters. Traduzido por: Malcolm DeBevoise. Cambridge, EUA: Harvard University Press, 2004.

CENTENO, Miguel Angel. Blood and Debt: War and the Nation-State in Latin America. University Park, EUA: Penn State University Press, 2003.

COSTA, Emilia Viotti da. The Brazilian Empire: Myths and Histories. Chapel Hill, EUA: The University of North Carolina Press, 2000.

CUNHA, Francisco X. Propaganda contra o Império. Reminiscências na imprensa e na diplomacia. 1870 a 1910. Rio de Janeiro: Imprensa Nacional, 1914.

GAMSA, Mark. Cultural Translation and the Transnational Circulation of Books. Journal of World History, Honolulu, v. 22, n. 3, pp. 553-575, 2011. Disponível em: https://www.jstor.org/stable/23011749?seq=1\#page_scan tab_contents Acesso: fevereiro 2019. 
GOEBEL, Michael. Overlapping Geographies of Belonging: Migrations, Regions, and Nations in the Western South Atlantic. Washington, EUA: American Historical Association, 2013.

GOEBEL, Thomas Michael. Globalization and Nationalism in Latin America, c.1750-1950. New Global Studies, Berlin/Boston, v. 3, n. 3, pp. 1-24, 2009. Disponível em: https://www.degruyter.com/view/j/ngs.2010.3.3/ngs.2010.3.3.1091/ngs.2010.3.3.1091.xml?fo rmat=INT Acesso: fevereiro 2019.

GOLDFAJN, Tal; PREUSS, Ori; SITMAN, Rosalie. Introduction or Why Should Historians of Modern Latin America Take Translation Seriously? Estudios interdisciplinares de América Latina y el Caribe, Tel Aviv, v. 21, n.1, pp. 9-15, 2010. Disponível em: http://eial.tau.ac.il/index.php/eial/article/view/294 Acesso: fevereiro 2019.

GRAHAM, Richard. Britain and the Onset of Modernization in Brazil, 1850-1914. Cambridge: Cambridge University Press, 1968.

HERMANS, Theo. Descriptive Translation Studies. The Encyclopedia of Applied Linguistics. Chichester, West Sussex, UK: Wiley-Blackwell, 2012. Disponível em: http://onlinelibrary.wiley.com/doi/10.1002/9781405198431.wbeal0315/pdf. Acesso: fevereiro 2019.

158 HERNANDO, Bernardino M. Traducción y periodismo o el doble y misterioso escepticismo. Estudios sobre el Mensaje Periodístico, Madrid, Espanha, n. 5, pp. 129-141,1999. Disponível em: http://revistas.ucm.es/index.php/ESMP/article/view/ESMP9999110129A Acesso:

fevereiro 2019.

LAERA, Alejandra. Cronistas, novelistas: la prensa periódica como espacio de profesionalización en la Argentina (1880-1910). In: ALTAMIRANO, Carlos. (dir.). MYERS, Jorge (ed.). Historia de los intelectuales en América Latina. vol. 1, La ciudad letrada, de la conquista al modernismo. Buenos Aires: Katz, 2008, pp. 495-522.

MÁRMOL, José. Juventude progressista do Rio de Janeiro. Ostensor Brazileiro. Jornal literário e pictorial, Rio de Janeiro, n. 44, 48, pp. 351-352, 382-385, 1846. Disponível em: http://memoria.bn.br/DocReader/DocReader.aspx?bib=700100x\&PagFis=1 Acesso: fevereiro 2019.

MILLER, Nicola. The Historiography of Nationalism and National Identity in Latin America. Nations and Nationalism, v. 12, n. 1, pp. 201-221, 2006. Disponível em: https://onlinelibrary.wiley.com/doi/full/10.1111/j.1469-8129.2006.00237.x Acesso: fevereiro 2019.

MITRE, Bartolomé. La abolición de la esclavitud en el Brasil: discurso dirigido al ministro brasileño en Buenos Aires en nombre del pueblo argentino, maio 19 de 1888. In: MITRE, Bartolomé. Arengas de Bartolomé Mitre. Buenos Aires: Biblioteca de la Nación, 1902, vol. 3, pp. 89-93.

PREUSS. "Povos quase da mesma língua”: não-/tradução, modernização, e as relações Brasil-Argentina, 18651900

Belas Infiéis, v. 8, n. 2, pp. 135-164, 2019. DOI: 10.26512/belasinfieis.v8.n2.2019.24385 
MORETTI, Franco. More Conjectures. New Left Review, Londres, v. 20, pp. 75-81, 2003. Disponível em: https://newleftreview.org/II/20/franco-moretti-more-conjectures Acesso: fevereiro 2019.

MOYA, José C. Modernization, Modernity, and the Trans/formation of the Atlantic World in the Nineteenth Century. In: CANIZARES-ESGUERRA, Jorge; SEEMAN, Erik R. (ed.). The Atlantic in Global History, 1500-2000. Upper Saddle River, EUA: Prentice Hall, 2006, pp. 179-198.

Museo Mitre. “Museo Mitre,” Catálogo de la biblioteca. Buenos Aires: Impr. de M. Biedma é hijo, 1907.

NEEDELL, Jeffrey. Rio de Janeiro and Buenos Aires: Public Space and Public Consciousness in Fin-de-Siècle Latin America. Comparative Studies in Society and History, Cambridge, Reino Unido, v. 37, n. 3, pp. 519-540, 1995. Disponível em: https://www.jstor.org/stable/179218?seq=1\#page_scan_tab_contents Acesso: fevereiro 2019.

NEUMAN, Iver B. Self and Other in International Relations. European Journal of International Relations, Londres, Reino Unido, v. 2, n. 2, pp. 139-174, 1996. Disponível em: https://journals.sagepub.com/doi/10.1177/1354066196002002001 Acesso: fevereiro 2019.

Páginas históricas: polémica de la Triple Alianza: correspondencia cambiada entre el Gral. Mitre y el Dr. Juan Carlos Gómez. Impr. La Mañana, 1897.

PARANHOS, José Maria da Silva (Visconde do Rio Branco). A convenção de 20 de fevereiro demonstrada à luz dos debates do Senado e dos successos da Uruguayana. Rio de Janeiro: B.L. Garnier, 1865.

PREUSS, Ori. Brazil into Latin America: The Demise of Slavery and Monarchy as Transnational Events. Luso-Brazilian Review, Madison, EUA, v. 49, n.1, pp. 96-126, 2012. Disponível em: http://lbr.uwpress.org/content/49/1/96.abstract.pt Acesso: fevereiro 2012.

PREUSS, Ori; SCARFI, Juan Pablo. Relaciones internacionales, identidades colectivas y vida intelectual en América Latina, 1810-1945. Revista Complutense de Historia de América, Madrid, Espanha, v. 39, pp. 15-21, 2013. Disponível em http://revistas.ucm.es/index.php/RCHA/article/viewFile/43833/41442 Acesso: fevereiro 2019.

PYM, Anthony. Translation and Text Transfer: an Essay on the Principles of Intercultural Communication. Frankfurt am Main, Berlin, Bern, New York, Paris, Vienna: Peter Lang, 1992.

QUESADA, Vicente G. Mis memorias diplomáticas: misión ante el gobierno del Brasil. Buenos Aires: Impr. De Coni Hermanos, 1907.

RAMA, Ángel. Algunas sugerencias de trabajo para una aventura intelectual de integración. In: PIZARRO, Ana (org.). La literatura latinoamericana como proceso. Buenos Aires: Centro Editor de América Latina, 1985, pp. 85-97.

PREUSS. "Povos quase da mesma língua”: não-/tradução, modernização, e as relações Brasil-Argentina, 18651900

Belas Infiéis, v. 8, n. 2, pp. 135-164, 2019. DOI: 10.26512/belasinfieis.v8.n2.2019.24385 
RAMA, Ángel. The Lettered City. Traduzido por: John Charles Chasteen. Durham: Duke University Press, 1996.

RAMOS, Julio. Divergent Modernities: Culture and Politics in 19th Century Latin America. Durham: Duke University Press, 2001.

ROMERO, Silvio. Literatura brasilera: sus relaciones con el 'neo-realismo. NRBA 3, 1881, pp. 483-507.

SÁBATO, Hilda. On Political Citizenship in Nineteenth-Century Latin America. The American Historical Review, New York/London/Washington, v. 106, n. 4, pp. 1290-1315, 2001. Disponível em: https://academic.oup.com/ahr/article-abstract/106/4/1290/80703 Acesso: fevereiro 2019.

SÁBATO, Hilda. The Many and the Few: Political Participation in Republican Buenos Aires. Stanford: Stanford University Press, 2001.

SARMIENTO, Domingo Faustino. Civilización y barbarie. Vida de Juan Facundo Quiroga y aspecto físico, costumbres y hábitos de la República Argentina. Santiago: Imprenta del Progreso, 1845.

SCHARLAU, Birgit. Traducir en América Latina: Genealogía de un tópico de investigación. 160 Estudios. Revista de Investigaciones Literarias y Culturales, Venezuela, n. 24, pp. 15-33, 2004.

SHAMMA, Tarek. Postcolonial studies and translation theory. MonTI. Monografías de Traducción e Interpretación, Alicante, Espanha, v. 1, pp. 183-196, 2009. Disponível em: http://www.redalyc.org/pdf/2651/265119728014.pdf Acesso: fevereiro 2019.

SHUMWAY, Nicolas. The Invention of Argentina. California, EUA: University of California Press, 1993.

SILVA, Eduardo. Cronologia. In: SILVA, Eduardo (ed.). Idéias políticas de Quintino Bocaiúva. 2 vols. Brasília/Rio de Janeiro: Senado Federal/Casa Rui Barbosa, 1986.

SMITH, Anthony D. National Identity. EUA: University of Nevada Press, 1991.

SORÁ, Gustavo. Traducir El Brasil: Una Antropología de La Circulación Internacional de Ideas. Buenos Aires; Libros del Zorzal, 2003.

TOURY, Gideon. A Handful of Paragraphs on "Translation" and "Norms". Current Issues in Language and Society, Reino Unido, v. 5, n.1-2, pp. 10-31, 1998. Disponível em: https://www.tandfonline.com/doi/abs/10.1080/13520529809615501 Acesso: fevereiro 2019.

WAISMAN, Sérgio. Foundational Scenes Translation. Estudios interdisciplinares de América Latina y el Caribe, Tel Aviv, v. 21, n.1, pp. 53-75, 2010. Disponível em: http://eial.tau.ac.il/index.php/eial/article/view/298/269 Acesso: fevereiro 2019.

PREUSS. "Povos quase da mesma língua": não-/tradução, modernização, e as relações Brasil-Argentina, 18651900

Belas Infiéis, v. 8, n. 2, pp. 135-164, 2019. DOI: 10.26512/belasinfieis.v8.n2.2019.24385 
WERNER, Michael; ZIMMERMANN, Bénédicte. Beyond Comparison: Histoire Croisée and the Challenge of Reflexivity. History and Theory, Connecticut, EUA, v. 45, n. 1, pp. 30-50, 2006. Disponível em: https://www.jstor.org/stable/3590723?seq=1\#page_scan_tab_contents Acesso: fevereiro 2019.

WINSECK, Dwayne R.; PIKE, Robert M. Communication and Empire: Media, Markets, and Globalization, 1860-1930. Durham: Duke University Press, 2007.

ZANETTI, Susana. Modernidad y religación: una perspectiva continental (1880-1916). In: PIZARRO, Ana (org.) América Latina: Palabra, Literatura e Cultura. Volume 2: Emancipaçao do Discurso. São Paulo, Memorial da América Latina, Unicamp, 1994, pp. 489-534.

\footnotetext{
${ }^{1}$ Este artigo é uma versão revisada do primeiro capítulo do livro Transnational South America: Experiences, Ideas, and Identities, 1860-1920, intitulado "Almost the Same Language": Translation, International Relations, and Identification. Esta tradução foi revisada e autorizada pelo professor Ori Preuss por meio do e-mail belasinfieis@gmail.com.

O livro Transnational South America: Experiences, Ideas, and Identities, 1860-1920 de autoria de Ori Preuss em 2016 pela Routledge. Conforme o item 3.2 alínea A do contrato assinado por Preuss com a Routledge, o autor concede aos editores o direito e a licença única e exclusiva para produzir e publicar, e sublicenciar a Obra ou qualquer adaptação ou tradução, ou qualquer parte da Obra, em todas as formas e suportes, em todas as línguas exceto espanhol e português.

${ }^{2}$ Ori PREUSS - Doutor em História da América Latina (2005), University of Miami, EUA. Graduado em História e História do Oriente Médio, Universidade de Tel Aviv, Israel. Professor titular de História da América Latina, Departamento de História, Universidade de Tel Aviv. Co-editor da revista acadêmica Estudios Interdisciplinarios de América Latina y el Caribe (EIAL). Tel Aviv, Israel.

ORCID: https://orcid.org/0000-0002-5470-3479

Currículo acadêmico: https://en-humanities.tau.ac.il/profile/opreuss

E-mail: oripreuss@gmail.com

${ }^{3}$ I would like to thank the late Dan Daor for opening the door for me to translation as a practice, and Tal Goldfajn for introducing me into translation as a field of study.

Eu gostaria de agradecer ao saudoso Dan Daor por me abrir as portas a tradução como prática, e a Tal Goldfajn por me introduzir na tradução como um campo de estudo. [Tradução nossa]

${ }^{4}$ Patrícia Rodrigues COSTA - Doutora em Estudos da Tradução (2018) pela Universidade Federal de Santa Catarina (UFSC), tendo sido bolsista CAPES-DS e realizado estágio doutoral (CAPES - PDSE) na Université de Montréal (UdeM), Canadá, sob orientação do Prof. Dr. Georges L. Bastin de agosto a dezembro de 2017. Ainda durante o doutorado, foi contemplada com a bolsa do governo canadense relativa ao Programa Futuros Líderes das Américas (Programme des futurs leaders dans les Amériques - PFLA) para realização de estágio de pesquisa na Université de Montréal (UdeM), Canadá, sob orientação do Professor Doutor Álvaro Echeverri de agosto 2014 a fevereiro 2015. Mestre em Estudos de Tradução (2013), Bacharel em Agronomia (2014) e Bacharel em Letras/Tradução - Inglês (2008) pela Universidade de Brasília. É pós-doutoranda do Programa de Pós-Graduação em Estudos da Tradução (POSTRAD) da Universidade de Brasília. É editora da Revista Belas Infiéis (ISSN 23166614) desde sua criação e é editora assistente desde 2013. Brasília, Distrito Federal, Brasil.

ORCID: https://orcid.org/0000-0002-3254-8914

Currículo acadêmico: http://lattes.cnpq.br/9546437584230118

E-mail: prcosta1986@gmail.com

${ }^{5}$ Rodrigo D’AVILA - Doutorando em Estudos da Tradução pela Universidade Federal de Santa Catarina, bolsista CAPES-DS. Mestre (2016) em Estudos da Tradução. Durante o mestrado, foi contemplado com a bolsa do governo canadense relativa ao Programa Futuros Líderes das Américas (Programme des futurs leaders dans les Amériques - PFLA) para realização de estágio de pesquisa na Université de Montréal (UdeM), Canadá, sob orientação do Professor Doutor Georges L. Bastin de agosto 2014 a fevereiro 2015. Bacharel em Letras - Tradução/Francês (2015) pela Universidade de Brasília. Bacharel em Relações Internacionais (2006) com ênfase em Comércio Exterior e Marketing pela Universidade Católica de Brasília (2006), atuando em empresas de Comércio Exterior e prestando consultoria na área de Marketing e Trade Marketing. É editor da revista Belas Infiéis (ISSN 2316-
}

PREUSS. "Povos quase da mesma língua”: não-/tradução, modernização, e as relações Brasil-Argentina, 18651900

Belas Infiéis, v. 8, n. 2, pp. 135-164, 2019. DOI: 10.26512/belasinfieis.v8.n2.2019.24385 
6614) desde sua criação, sendo responsável pela revisão de provas, pela diagramação e pelo layout; é editorassistente desde 2017. Florianópolis, Santa Catarina, Brasil.

ORCID: https://orcid.org/0000-0001-6650-1674

Currículo acadêmico: http://lattes.cnpq.br/1746993519090773

E-mail: rodrigodavilabraga@gmail.com

${ }^{6}$ Lia Araujo Miranda de LIMA - Doutoranda em Literatura pela Universidade de Brasília (POSLIT/UnB) com bolsa CAPES-DS. Mestre em Estudos da Tradução pela Universidade de Brasília (2015). Graduada em LetrasTradução), com habilitação em Francês, pela Universidade de Brasília (2008) e em Comunicação Social, com habilitação em jornalismo, pela Universidade Federal de Minas Gerais (2004). É membro da International Research Society for Childrens Literature (IRSCL). Brasília, Distrito Federal, Brasil.

ORCID:

Currículo acadêmico: http://lattes.cnpq.br/8248385539458046

E-mail: liaamiranda@gmail.com

${ }^{7}$ Giovana BLEYER - Doutora em Estudos da Tradução (2014) pela Universidade Federal de Santa Catarina com estadia de pesquisa na Artesis University College de setembro de 2013 a janeiro de 2014, tendo sido bolsista do Programa de Doutorado Sanduíche no Exterior (PDSE) da Coordenação de Aperfeiçoamento de Pessoal de Nível Superior (CAPES). Mestre em Literatura e Práticas Sociais (2009) pela Universidade de Brasília. É licenciada em Francês (2007) e bacharel em Letras - Estudos Literários (2008) pela Universidade Federal de Goiás. É graduanda em Letras - Inglês pela Universidade Federal de Goiás. Realizou estágio de pós-doutorado em Letras e Linguística (2016) pela Faculdade de Letras da Universidade Federal de Goiás, tendo sido bolsista FAPEG/CAPES. É especialista em Linguística das Línguas de Sinais (2018) pela Universidade Federal de Goiás. Atualmente é professora substituta na Universidade Federal de Goiás. Goiânia, Goiás, Brasil.

ORCID: https://orcid.org/0000-0002-7461-1977

Currículo acadêmico: http://lattes.cnpq.br/4587657087203729

E-mail: giovanableyer@gmail.com ${ }^{8}$ VARELA, Luis Vicente. El Brasil y la Argentina: confraternidad sud-americana; obra descriptiva, ilustrada
con fotograbados de las más importantes festividades; Pub. por la Intendencia municipal de la capital de la República Argentina. Buenos Aires: Impr. de J. Peuser, 1901, pp. 359-360.

${ }^{9}$ RODRÍGUEZ DEL BUSTO, Antonio. "Unión de los afluentes navegables del Amzonas y del Plata," In: Terceira reunião do congresso scientifico latino-americano celebrada na cidade do Rio de Janeiro em 6 a 16 de agosto de 1905: relatorio geral, ed. Antonio P. Freitas (Rio de Janeiro: Imprensa nacional, 1906), tomo II, pp. 201-246.

${ }^{10}$ Werner e Zimmermann (2006, p. 43). Sobre a negligência das abordagens transnacionais por parte dos latinoamericanistas, ver Miller (2006, p. 216).

${ }^{11}$ Sobre "culture area", ver Smith (1991, pp. 171-173). Citação de Goebel (2009, pp. 7-9). Sobre o nível legal de alteridade cultural e de alteridade nacional na América Latina, conferir também Centeno (2003, pp. 90-91, 175).

${ }^{12}$ Zanetti (1994), Rama (1985)

${ }^{13}$ Sigo a distinção que Antony Pym, acadêmico dos Estudos da Tradução, em Translation and Text Transfer, faz entre "transfer as material movement and translation as a semiotic activity, with the two related in such a way that translation not only responds to transfer but can also represent or misrepresent its materiality" ["transferência como um movimento material e tradução como uma atividade semiótica, ambos relacionados de tal modo que tradução não somente corresponde a tradução, mas também representa ou deturpa sua materialidade" (1992, pp. 13-14. Tradução nossa)]. Em "Cultural Translation and the Transnational Circulation of Books", o historiador Mark Gamsa faz um apelo semelhante para unir a "analysis of intellectual flows with that of commodity transfer, realms hitherto usually approached in separation from each other" ["análise dos fluxos intelectuais com a da transferência de produtos, campos até então geralmente abordados separadamente uns dos outros" (GAMSA, 2011, p. 574. Tradução nossa)].

${ }^{14}$ Burke e Hsia, "Introducing", pp. 2-3.

Para o caso da América Latina, conferir Goldfajn, Preuss, Sitman (2010) e Bastin (2006).

${ }^{15}$ Para uma definição do paradigma descritivo, conferir Hermans, "Descriptive Translation Studies." (2012).

${ }^{16}$ Scharlau (2004), "Traducir en América Latina."

${ }^{17}$ Sobre a reificação da diferença como uma fraqueza das abordagens pós-coloniais à tradução, conferir Shamma (2009), "Postcolonial studies and translation theory."

${ }^{18}$ Para esclarecimentos sobre estes termos, conferir Franco Moretti (2003).

${ }^{19}$ Casanova (2004, pp. 17-19)

Sobre o status do francês na América Latina, ver Candido (1995, pp. 127-130).

${ }^{20}$ Embora a história do jornalismo tenha se entrelaçado com a prática da tradução desde a sua origem no século XVIII, os Estudos Históricos sobre a Tradução - especialmente de textos não-literários - em jornais e revistas são extremamente raros. Para uma discussão acerca dessa lacuna, ver Hernando (1999). No caso da América Latina,

PREUSS. "Povos quase da mesma língua”: não-/tradução, modernização, e as relações Brasil-Argentina, 18651900

Belas Infiéis, v. 8, n. 2, pp. 135-164, 2019. DOI: 10.26512/belasinfieis.v8.n2.2019.24385 
alguns trabalhos pioneiros foram publicados recentemente sobre a tradução em periódicos durante o período da independência (cf. BASTIN; ITURRIZA, 2008).

${ }^{21}$ Neumann (1996), "Self and Other in International Relations." Para o caso latinoamericano ver Preuss and Scarfi (2013).

${ }^{22}$ Moya, "Modernization, Modernity", pp. 190-191.

${ }^{23}$ Sabato (2001, pp. 1309), "On Political Citizenship".

${ }^{24}$ Rama (1996, pp. 51-52), The Lettered City.

${ }^{25}$ Em A Handful of Paragraphs, Toury (1998, pp. 19-20) estabelece uma distinção "entre o ato de traduzir, que é de fato cognitivo, e o contexto ou situação em que a pessoa que realiza o ato e, portanto, o ato em si, estão cravados, o que às vezes tem sido chamado de evento tradutório. ["between the act of translation, which is indeed cognitive, and the context or situation where the person performing the act, and hence the act itself, are embedded, which has sometimes been called the translation event." (Nossa tradução).] A noção correspondente de "scene" (cena, cenário), no sentido de "tempo e espaço específicos entre línguas, entre textos" é retirada de "Foundational Scenes Translation" de autoria de Waisman (2010, pp. 54)

${ }^{26}$ Tal como Michael Goebel observa astutamente em Overlapping Geographies of Belonging (2013), diversos conflitos militares na região do Rio da Prata durante o século XIX, inclusive a Guerra do Paraguai, "se referiam a um espaço comum e raramente opunham as lealdades nacionais umas às outras, mesmo que contribuíssem para produzi-las" ["referred to a common space and rarely opposed national loyalties against one another, even if they contributed to producing them"].

${ }^{27}$ Shumway, The Invention of Argentina, pp. 242-248; Baratta, "La oposición a la Guerra."

${ }^{28}$ Paranhos, A convenção.

${ }^{29}$ Mitre a Rio Branco, quartel general, Paso de los Libres, Setembro 26, 1865; Mitre a Rio Branco, quartel general, Ensenadita, janeiro 5, 1866, transcrito em Cadernos do CHDD 4.6 (2005), pp. 168-169.

${ }^{30}$ Páginas históricas, 101-106. Museo Mitre, Catálogo de la biblioteca, 67.

31 Páginas históricas, 10.

${ }^{32}$ Mármol, "Juventude progressista, 384. Significativamente, do ponto de vista da tradução e da circulação transnacional, o artigo foi adaptado para o espanhol por Mármol e republicado no ano seguinte no Uruguai com o título: Examen crítico de la juventud progresista del Río Janeyro (Montevideo, Imprenta de la Caridad, 1847). Em seu monumental trabalho sobre os escritores argentinos exilados no Brasil durante o governo ditatorial do caudilho Juan Manuel de Rosas (1829-1852), Adriana Amante dedica várias páginas (Poéticas y políticas del destierro, pp. 451-454) à questão da linguagem, mencionando alguns casos de potencial tradução naquele período, incluindo o artigo de Mármol. Os escritos deste último em português, de acordo com Amante, tinham muitas estruturas gramaticais semelhantes às do espanhol, o que sugere que eles poderiam ter sido traduzidos ou pelo menos corrigidos.

${ }^{33}$ Páginas históricas, 23-24.

${ }^{34}$ Costa, The Brazilian Empire, 72-75.

${ }^{35}$ Ver, por exemplo, Graham, Britain.

36 "Notícias do Exterior," A Reforma, December 24, 1869, n.p.

${ }^{37}$ Graham, Britain, 255; Sodré, História da imprensa, 211.

SODRÉ, Nelson Werneck. História da imprensa no Brasil. Rio de Janeiro: Mauad Editora, 1999.

${ }^{38}$ Francisco Octaviano, "O tractado [sic] da aliança (prefacio)," A Reforma, janeiro, 11, 1870, 1.

${ }^{39} \mathrm{O}$ texto fundacional desta tradição é de Domingo Faustino Sarmiento, Civilización y barbarie: vida de Juan Facundo (1845).

40 Octaviano, "O tractado [sic] da aliança (prefacio)," 1.

41 Werner e Zimmermann (2006, p. 38)

${ }^{42}$ Silva, "Cronologia," vol. 1, 21-25.

${ }^{43}$ Cunha, Propaganda contra o imperio, 71.

44 Páginas históricas, 58, 67.

${ }^{45}$ Ibid., 59-63.

${ }^{46}$ Gazeta de Notícias [GN], 21 de agosto de 1883, 2, citado em Vicente G. Quesada, Mis memorias diplomáticas, 216.

47 Vicente G. Quesada, "Prospecto,” Revista del Paraná 1 (1861): 1-2.

48 "Prospecto," La Revista de Buenos Aires: Historia Americana, Literatura y Derecho 1 (1863): 3-4.

${ }^{49}$ Vicente G. Quesada, "Prospecto," NRBA 1 (1881): 3-8. e

50 "Fiesta literaria," NRBA 8 (1883), 473.

${ }^{51}$ Romero, "Literatura brasilera."

52 "Fiesta literaria," NRBA 8 (1883). É importante ressaltar que esta coleção também foi publicada, separadamente, em Buenos Aires como um panfleto intitulado: Confraternidad intelectual latino-americana, 1883.

PREUSS. "Povos quase da mesma língua”: não-/tradução, modernização, e as relações Brasil-Argentina, 18651900

Belas Infiéis, v. 8, n. 2, pp. 135-164, 2019. DOI: 10.26512/belasinfieis.v8.n2.2019.24385 
${ }^{53}$ Ernesto Quesada, "Rio de Janeiro, NRBA 8 (1883); GN September 28, 29, October 2, 10.
${ }^{54}$ Vicente G. Quesada, Mis memorias diplomáticas, 359.
${ }^{55}$ Ver, sobre a imprensa brasileira, Alonso, Idéias em movimento (pp. 276-283); Sodré, História da imprensa, 201

55 Ver, sobre a imprensa brasileira, Alonso, Idéias em movimento (pp. 276-283); Sodré, História da imprensa, 201-
250. Sobre a imprensa argentina: Laera, "Cronistas, novelistas"; Ramos, Divergent Modernities, 95; Sábato, The Many and the Few, 44-51; Ramos, Divergent Modernities, 91-107.

${ }^{56}$ Winseck, e Pike, Communication and Empire, 72.

57 Preuss, "Brazil into Latin America."

58 "La manifestación al Brasil," La Nación (Asunción), maio 23, 1888; "La abolición de la esclavitud en el Brasil," "Teatros-Función de Gala en honor del Brazil," Ferro Carril (Santiago de Chile), maio 18, 1888; "No más esclavos," El Siglo (Caracas), maio 21, 1888. Esses artigos foram anexados em despachos enviados por ministros brasileiros nas respectivas capitais para o ministro das Relações Exteriores no Rio de Janeiro. Os eventos em Buenos Aires foram relatados em detalhe na imprensa do Rio. Por exemplo, Jornal do Commercio, "Telegrammas" section, maio $18,1889,1$.

${ }^{59}$ Mitre, "la abolición de la esclavitud," vol. 3, 89-93. Uma transcrição do discurso foi enviada pelo ministro brasileiro, Buenos Aires, para o Ministro das Relações Exteriores, Rio de Janeiro, 31 de maio de 1888, Arquivo Histórico do Itamaraty (Rio de Janeiro) [AHI].

${ }^{60}$ Gazeta de Notícias, 18 de maio de 1888, 2. Discurso de Mitre, juntamente com outras notas de congratulações de toda a Argentina, foram coletadas e publicadas em Buenos Aires como um livreto intitulado La fiesta de la libertad. O plenipotenciário brasileiro enviou 500 cópias desse volume para seu ministro no Rio de Janeiro, seguido de um despacho informando que o discurso de Mitre mereceu atenção tanto pelo seu significado quanto pelo seu conteúdo. Dispachos, 23 e 31 de maio de 1888, AHI.

61 República Argentina, Tratado de Misiones, 31-32.

${ }^{62}$ Needell, "Rio de Janeiro and Buenos Aires," 519-521.

63 "Nao desafinemos," A Imprensa, Agosto 2, 1899, Obras Completas, vol. XXVI, t. VI, 194.

${ }^{64}$ Ministro argentino Manuel Gorostiaga, Petrópolis, a Rui Barbosa, Agosto 2, 1899, Arquivo da Casa de Rui

164 Barbosa (Rio de Janeiro), CR 1589.1/1.

${ }^{66}$ Ministro brasileiro, Washington, ao Ministro das Relações Exteriores, RJ, 31 de janeiro de 1900, em Assis Brasil, Um diplomata da República, vol. 1, 253.

${ }^{67}$ Varela, El Brasil y la Argentina, traz centenas de páginas de discursos e reportagens em ambos os idiomas. Ver também La Revista Patriótica, 1900; “Brasil," edición especial de La Ilustración Sud-Americana en honor del Excmo. Sr. Presidente de los Estados Unidos del Brasil, Dr. Manuel Ferraz de Campos Salles en ocasión de su visita á la República Argentina, La Revista Patriótica, vols. 87, and 88 (outubro de 1900) de La Ilustración SudAmericana Revista Ilustrada de las Repúblicas Sud-Americanas.

O título deste periódico em si demonstra a formação de um espaço regional.

${ }^{68} \mathrm{O}$ caso mais notavel foi El Brasil intellectual: impresiones y notas literarias, do escritor-diplomata Martín García Merou, que atuou como ministro argentino no Brasil entre 1894 e 1896. Compreendendo muitas traduções fragmentárias de textos brasileiros, o livro foi publicado na época da visita de Campos Sales "sob a impressão da gratificante corrente da simpatia viva e sincera fraternidade solidamente estabelecida entre as duas nações" ["under the impression of the gratifying current of lively sympathy and sincere fraternity solidly established between the two nations" (pp. v-vi)].

${ }^{69}$ Sorá, Traducir el Brasil, pp. 71-98.

70 "to define the limits of a culture as the points where transferred texts have had to be (intralingually or interlingually) translated. That is, if a text can adequately be transferred without translation, there is cultural continuity. And if a text has been translated, it represents distance between at least two cultures. In this way, translation studies avoids having to link up all the points of contiguity in the way that political frontiers do. After all, there is no obvious reason why points of contact and exchange between cultures should form continuous lines. Culture is not geo-politics. Transfer and translation concern situations of contact and exchange, not lineal separations." (PYM, 1992, pp. 25-26. Tradução nossa)

${ }^{71} \mathrm{O}$ próprio Pym quase reconhece tais casos quando observa que "entre esses dois extremos - monoculturas extensivas reveladas pela não-tradução; fronteiras culturais reveladas pela tradução - há comunidades biculturais onde é difícil decidir se a tradução atravessa uma fronteira cultural ou não" ["between these two extremesextensive monocultures revealed by non-translation; cultural frontiers revealed by translation - there are bicultural communities where it is difficult to decide if translation crosses a cultural frontier or not."']. (PYM, 1992, pp. 2526)

PREUSS. "Povos quase da mesma língua”: não-/tradução, modernização, e as relações Brasil-Argentina, 18651900

Belas Infiéis, v. 8, n. 2, pp. 135-164, 2019. DOI: 10.26512/belasinfieis.v8.n2.2019.24385 